\title{
Maintaining and Improving the Environmental Cleanliness in Semarang Municipality in the Era of Industrial Revolution 4.0
}

\author{
Oktiva Herry Chandra ${ }^{1}$ \\ ${ }^{1}$ Department of English Literature, Faculty of Humanities, Diponegoro University, Semarang - Indonesia
}

\begin{abstract}
Language produced in a specific event of communication will have its form and function. Some messages are delivered in direct ways meaning the form and the functions are symmetric; some others are delivered in indirect ways, asymmetric. Direct or indirect ways will give different perceptions to those who receive the content of the message. Considering the face of receivers is one of the principles that should be made by policy makers as they communicate with people in public space. This article aims to explain the forms of language used to prohibit littering and the way the maker of prohibition thinks about the writing of littering. The research is conducted by using non-participatory observation method. This, then, is followed by applying note taking technique and recording. The result shows mostly the writings of littering prohibition are made an indirect way and less number in indirect way. Having a direct way means society is placed as subordinate in relation to the authorities. Even though less in number, indirect littering prohibition shows some writings see an equal position between the writer and reader. Both take a similar point of view on littering.
\end{abstract}

Keywords: form; function; direct; indirect; public space; and social interaction.

\section{Introduction}

Recently, in the era of industrial revolution 4.0, easily accessed media to figure out information coming from a very distant place facilitate people and various issues recently happened in short times. This is done by the progress in spreading information through information technology.

One of the common issues is about the flood. The news broadcasted flood as their main headlines a few times. It has been the domineering topic in several media, either local media or national one. There are many core problems as the source of the occurring flood, starting from the deforestation, bad drainage arrangement, to the classic one, trash. For some people, trash is the main reason for the flood, for the number of trashes found in rivers, has turned into heaps and clogged the water flow. Years have gone by and the problem has grown instead of lessening. The latest news heard nowadays is how busy the Government of Semarang municipality on carrying the trash that has accumulated to tens of tons. This issue goes furthermore viral when the trash problem becomes a political commodity and that trash has become the star of the news.

The effort done by the city's sanitary agents is not small in number. The allocation of budget for garbage transportation is not cheap either. Facilities such as the waste disposal are readily available in several places, as well as garbage transportation for neighborhood associations to other wider range but even so, the amount of efforts and facilities still result in incompetent garbage handling. In the writer's opinion, any amount of attempts put forth by the government to handle wastes will not succeed well without any support and the cooperation of the citizens. With the flood happening, it should be known to them that this has become a big exclamation mark that the citizens must know what to do. However, knowing what they have to do is different from what they will do. There are several reasons regarding the reluctance of throwing garbage properly and from all those factors, the writer wants to inspect how the authorities, both citizens and government, have given orders to manage or throw garbage through the help of billboards stating the prohibition of littering or in the different written forms. How to convey messages through a written form is an important factor that can trigger the inner consciousness of the people not to litter or on the contrary, they will pay no heed to the request because of the lack of sympathy aroused by the writings. The correct words can invoke empathy, but we have to give society a beneficial profit and to place society as a subject, not an object.

Have the competent parties put forth their attention to trash problems to the use of correct language? This article will analyze slightly the objective facts, which contain various shapes and forms of littering prohibition in the society. The main purpose is to figure out the forms of language used to prohibit littering and the point of view of the maker towards littering prohibition. This also aims to find out the best solution to create a society

* Corresponding author: herrychandra67@,gmail.com 
where empathy exists to problems of maintaining cleanliness with the use of proper language.

\section{Theoretical Framework}

For someone who believes in functionalism, communication, verbal or written, cannot be seen as an individual lingual transaction in the form of words, phrases, and sentences. More than that, every language code that can be produced by human speech organs are used in an interval to convey a function or manipulated by someone to reach the goals of their communication.

Austin [1] says that every utterance said a speaker in an occurrence would lead to three simultaneous acts. Those three acts are locutionary act, illocutionary act, and perlocutionary act. The act of locutionary is to create an utterance by activating the mechanism of all speech organs. The utterance produced will be one lingual unit that is accepted semantically and syntactically in the involving community. The meaning behind a locutionary act is on the same level as the meaning behind each word unit and grammatical, which is after the words are combined with other words to form a meaningful unit.

The second one is the illocutionary act or simply, illocution is the second thing that has to be done by a speaker. Instead of conveying an utterance, a speaker, in Austin's theory, will always use their utterance to do the function or certain goal. The function or goal in an utterance can be found as a meaning of the speaker's intention. The intention of the speaker in a communication act can be done implicitly, which then easily identified from the produced utterance because between the form of the utterances already showed the function of the said utterances, the speaker's intention has to be confirmed implicitly between the co-text and speech context.

The final act is the perlocutionary act, which is the speech act that is uttered to yield an impact or effect on those who listen or read the message. The impact done by an utterance can be translated as a form of response, by doing physical activity, do or undergo what the speakers have said, or by verbal communication which is to give feedback in the form of utterances.

From the intention of the speaker or the illocution ability in utterances, Searle [2] divided utterances into five different types, which are:

(1) Representative or otherwise known as assertive is a speech act that binds the speaker to declare utterance that contains truth, like to state, to report, to announce, or to explain certain things.

(2) The directive, a speech act that binds the speaker to do things as told by the speaker or someone in the utterance, such as to give order, to plead, to give advice, and to demand something.

(3) Expressive is a speech act that said with functions such as evaluating something that is mentioned in the utterance, such as to ask for forgiveness, to give criticism, to complain, and to disagree.

(4) Commissive, a speech act that will bind the speaker to carry out action told in the utterance if said, such as to make a promise, to swear, and to wager something.

(5) Declarative is a speech act that will bind the speaker to produce or concur a change of status or situation or people if said, such as to decide, to marry, to baptize and to give names.

Searle [2] divides the speech act into two different types, based on the lingual unit that forms an utterance or modus in a sentence and the function of the sentence in an utterance. The first one is a direct speech act, the second one is an indirect speech act. The first is symmetrical, meaning that direct speech act refers to all utterances that have their modus and utterance function as aligned. That means the speaker's intention in an utterance can be understood since the intention itself can be seen through the modus of the sentence used. For example, the modus of the sentence is imperative and functions as a term to order someone like what is shown in the utterance (1)

\section{(1) Buang sampah ini pada tempatnya.}

Throw the garbage properly.

As opposed to the direct speech, the indirect speech act was found to be asymmetrical between their modus and utterance function. In this context, the modus of a sentence can be used in a few types of function and a function that can be put forth through different modus of sentences [3]. For example, giving order can be realized by stating a few declarative modus such as (2)

(2) Saya merasa malu membuang sampah di sungai ini.

\section{I feel embarrassed for littering on this river.}

The degree of continuity between these four utterances is different from each other in terms of conveying order for someone to do. The degree of continuity can be measured through the distance between the speaker's utterance and the utterance comprehension of the listener. The longer time it takes, the higher the utterance's degree of discontinuity. Aside from that, the degree of continuity can be measured through its pragmatic clarity. The clearer the intention of the speaker, the more direct the utterance will be, and vice versa [4].

In order to fulfill all speech acts, whether it is direct or indirect, it all depends on a few extralingual factors that are related to the speaker, the interlocutors, and the situation. Manners or courtesy is one of the important factors that play a big role in deciding the form of utterance for the participants of the interaction. The base principle of courtesy is that it is a premise, filled with provisions that making sure the speaker feels comfortable when initiating an interaction process. Folley [5] says that courtesy is a social skill that is used to make sure every person involved in an interaction feels pleasant. Participants of the interaction will try to preserve each other's feelings so that no one feels disadvantaged or losing their faces. Brown and Levinson [6] call this phenomenon as face saving, a common thing done by the interaction participants due to some certain 
speech acts, such as the speech act of ordering and warning in which the two are included in the subsection of directive speech act and have the potential to facethreatening speech partner. In the context of courtesy of communicating, the speaker usually has to do a few strategies, both positive and negative strategies. Positive strategy is done by using a statement that is friendly, solidarity and praising, while negative strategy is done so that speech partner feels comfortable and not feel like their rights are violated $[7,8]$.

\section{Methodology}

The design of the researcher is qualitative. The locations of the research are western, northern, southern, eastern and center Semarang. The data were collected by using non-participatory observation method. This method was accompanied by two other techniques, namely, note taking technique and recording. By using these methods, the researcher collected data in the forms of writings containing prohibition for not littering garbage and maintenance for the cleanliness of the environment displayed in the open space area. These data were gained in several different locations in Semarang for one month. There were 100 writings taken as samples of the research. The data processing was done by classifying and grouping data. This was followed by analyzing data. The interview was also implemented to figure out the motivation behind making such writings. This was done by making a focused group discussion that was participated by some parties involved in the process of making littering prohibition.

\section{Finding and Discussion}

\subsection{Forms of Prohibiting Language}

From the collected data, namely the writings that contain prohibition towards littering, there are two types of speech acts used by the person who makes the prohibition. Two of those speech acts are both direct and indirect speech acts.

Prohibiting something is included in the speech act of directive where the person himself has given a pragmatic implication for people to heed the act as written in the prohibition. In the language realization, prohibition is realized both directly, using imperative sentences, and indirectly, by using declarative and interrogative sentences.

\subsubsection{Direct Speech Act}

Usually, this kind of sentence modus is used in the prohibition-type of directive speech act. These utterances are grouped as direct speech acts because the sentence modus and pragmatic implication are aligned, which already shows how the form and meaning of the utterances already show the pragmatic implication. Examples of this type of speech acts can be seen in the data below:

\section{Jangan buang sampah sembarangan} Do not litter (DT02)

2. Buanglah sampah pada tempatnya Put the trash in the right place (DT04)

3. Jangan buang sampah di sini Do not throw your trash here.

4. Dilarang buang sampah di sepanjang jalan ini Do not litter along this road. (DT010)

Judging from the number used, many people prefer to use direct sentence modus to make prohibition against the act of litter. For not letting misinterpretation happens, it is important to consider clarifying the prohibition for the people or the specified community this prohibition is intended to. The imperative sentence modus begins with the auxiliary verb of Do not, followed by verb phrases that contain the proposition on certain activities as seen in DT02's verb phrase litter and DT05's throw your trash here

The verb do not litter is also found in prohibitions, followed by verb phrases that explain certain activities, as seen in DT010. The use of prohibition-type of verbs will explain the aim of the prohibition creator.

The verbs used in directive pragmatic implication tend to be used and positioned first. The verb litter in DT04 implicates that the utterance is a prohibition, even if the literal meaning signifies a request. The pragmatic implication of it is the same as the other data, which is to forbid.

\subsubsection{Indirect Speech Act}

While there are many imperative sentences used indirect speech acts, indirect speech acts show that there are few sentence modus used. They are declarative and interrogative sentence modus, while exclamation sentence modus is not found in this research. The open location of the research is based on can be one of the reasons as well since exclamation sentences can only be found in the area that is slightly more private.

The writer managed to collect a few data samples for indirect speech acts and how dynamic the declarative sentence modus can be seen in the example below.

1. Terima kasih warga saya atas partisipasinya menjaga kebersihan dan menata keindahan.

Thank you for the participation of my citizens in keeping cleanliness and beauty "(DT 10)

2. Bersih itu indah Cleanliness is beautiful" (DT 15)

3. Anda memasuki kawasan tertib kebersihan You are entering orderly-maintained sanitation area (DT 21)

4. Bersih itu indah, bersih itu sehat (DT 11) Cleanliness is beautiful, clean equals healthy 


\section{Yang membuang sampah di sini anjing}

They who litters are dogs. (DT16)

The pragmatic implication of prohibiting in the utterance above does not show directly on the lingual unit that upholds it. To reach the correct interpretation and to build contextuality in the utterance, the premises have to be built around the utterance. In DT10, Thank you for the participation of my citizens in keeping cleanliness and beauty, the start of the contextuality begins in the verb phrase keeping cleanliness and beauty (DT10). Keeping and maintaining the beauty (of a place) means that people do not litter but throw garbages on their rightful place and that they are asked to keep the beauty of the existing environment.

The data found for interrogative sentence modus are not as many as the declarative sentence modus, few of them are:

1. Apakah susahnya membuang sampah pada tempatnya?

Is it that hard to throw trash correctly to its place?" (DT 12)

2. Apakah Anda sudah membuang sampah pada tempatnya?

Have you thrown trash to its place? (DT 22)

Much like the declarative modus, the interrogative modus is the alternative way to say the prohibition-type of directive speech act. The lingual unit and pragmatic implication are asymmetrical, so to ensure that the interpretation of the utterance as a prohibition is correct, it would need few premises to be built around the contexts of the utterance.

DT12 contains question about the capability of someone to throw trash to its place. It implies that putting trash to its rightful place is not that hard, if it is not hard then this activity can be done by any other person. With that in mind, this utterance has a pragmatic implication of throwing trashes to its designated places and not littering.

DT22 comes in the form of question whether or not we have put the trash to its correct place or not. This means as an appeal to throw trash at its designated places and a prohibition to litter.

\subsection{Society as Subject or Object.}

As seen from the collected data, the majority of the data were written by using direct sentences. This type of sentence signifies that there is a relation between society and a prohibition maker that is not symmetric. The maker of the prohibition has bigger authority compared to citizens. When using an imperative sentence, then the maker of the prohibition gains more power than the object of its goal and that creates a big distance between the maker of the rule and the citizens who read them. The consequences of that happening are the range of imposition can be stronger towards people who read the imperative prohibition.
For example, DT05 "Do not throw your trash here" the citizens who read this prohibition will be placed as the one who must obey and do what has been told because the power, distance, and range of imposition are too high. If the second party had given the relation between superordinate and subordinate as an acceptable connection, the imperative sentence modus in directive speech act will not inflict any problems. In fact, the second party will interpret the utterance as clear and does not have multiple interpretations. The second part will have two choices; to obey the prohibition or to be punished for breaking it. They realize the consequences dearly.

The feeling of being dictated and placed as a subordinate of power is the effect that arises from the reader of the prohibition, even though the prohibition is not only to ban the society from littering but also to spread awareness for the society to keep their environment clean. That awareness will take effect when the society is an advantageous one and the goodness of the invitation to do something. The imperative sentence modus places the society as the object of its goal and not the subject. With that, it is challenging to feel that thrash throwing activity is a common goal.

On the contrary, if the second party places the relation of superordinate and subordinate as an unacceptable relationship, because if the communication was done wrong and the point of view differs, then the imperative sentence modus is rendered ineffective. If the responsibility of keeping the environment clean as a common goal, then the second party will appreciate more of the prohibition that brings them in the same position, with the same rights and same responsibility. Interrogative and declarative sentence modus are demanded more and are more significant. In the DT10 statement, there is a statement that hinted how society is placed as the perpetrator for the common goal, which is to keep the environment clean. Else than that, they are given appreciation for what they have done and what they will do. Placing the society as a subject of social activity and at the same time, appreciate them for doing so is a real work to keep the face of the society.

Other attempts can be seen in DT15 and DT11 that places society as the party that will gain advantage from throwing trash in the proper place. The society was promised of a clean and healthy environment, so here, we are not talking about the prohibitor or authority that will gain advantage out of this, instead the society itself will. In the concept of Leech [9], the advantage has to be given to the speech partner, with that, they will be pleased and appreciated. Prohibition of littering can be seen as something that will be profitable for the society. In the future, the writer hopes that society will volunteer in taking care of the environment.

In DT12, the activity of throwing trash correctly is shown to be (actually) easy, so there is no other reason to litter. The clause Is it that hard to throw trash correctly to its place? can be seen in the interrogative sentence of DT12 that implicitly shows that the pragmatic implication of throwing trash correctly is an easy thing to do. With that, the writer hopes that there is no more 
reluctance to do so in the future and that it would be habitual for the society as implicated in DT22.

\section{Conclusion}

The speech act of prohibiting littering has been found around the society as an attempt to improve environmental quality. With the prohibition in place, it is hoped that it will spread awareness and obedience to keep the environment clean. Forms of the prohibition that are found in various sentence modus will give different perspectives amongst the citizens who read them. Forbidding signs will be the symbol between the creator and the user in symmetrical and asymmetrical relationships. Each has different consequences, if the creator's orientation is to spread awareness towards citizens about keeping the environment clean, the type of prohibition that is intended are prohibitions that have information, which defines society's role as a subject, and the ones who will receive the benefits and goodness. All those will give more impact if the society is technologically literate. In this case, people need to maximize the ability to use current technology in spreading information related to prohibition littering. They are not supposed to stuck in manual technology. By doing so, it will speed up the average of information delivering and the awareness of cleanliness in their surroundings.

\section{Acknowledgements}

I woukd like to address my deepest gratitude to the Dean of Humanities Faculty, Diponegoro University who has given this great oppurtunities to get involved in the program of scheme research.

\section{References}

1. J.L. Austin, How to Do Things with Words, New York : Oxford University Press (1969)

2. J.R Searle, A Taxonomy of Illocutionary Act in Syntax and Semantics, 3, Speech Acts, Cole, P. \& Morgan, J.L. (Eds.), New York: Academic Press (1979)

3. S. Blum-Kulka, Indirectness and Politeness in Request: same or different?, J. P. 11, 145-160 (1987)

4. A. Gunarwan, Pragmatik: Teori dan Kajian Nusantara, Jakarta: Universitas Atmajaya (2007)

5. W.A. Foley, Anthropological Linguistics: An Introduction, Oxford: Blackwell (2001)

6. P. Brown, S. Levinson, Universals in language Usage: Politeness Phenomena in Goody, EN (Ed.) Questions and Politeness: Strategies in Social Interaction, Cambridge: CUP (1987)

7. J. Verschueren, Understanding Pragmatics. London: Arnold (1999)

8. K. Allen, Linguistic Meanin, London: Routledge \& Kean Paul I (1986)
9. G. Leech, Principles of Pragmatics, London: Longman (1983) 